\title{
DIRECTION OF CAUSALITY BETWEEN FINANCIAL DEVELOPMENT AND ECONOMIC GROWTH EVIDENCE FROM EGYPT
}

Dr.Islam Mohamed EI Banna

Lecturer at Thebes Higher Institute for Computerand Management Sciences
Dr.Mamdouh Abdelmoula M.Abdelsalam Faculty of Commerce, Menoufyia University 


\section{ABSTRACT}

The connection of the causality between capital financial market development and economic growth has received much attention throughout last years. The long-run relationship between the level of financial development and economic performance is generally recognized and accepted (Goldsmith, 1969; King and Levine, 1993). The origin of these types of investigations is found in the research conducted by Schumpeter (1934). He argues that financial intermediaries are important for innovation and development .The current study derives its motivation from the notion that the finance-growth discourse should be narrowed down to individual countries. Therefore this study provides an empirical assessment relating to the linkage between financial development and economic growth in Egypt in the long run and in the short run. The study uses the model of Vector Error Correction Model (VECM) comprising GDP growth rate, some selected financial variables. The study found that GDP is negatively and significantly affected by both the real interest rate and the real exchange rate. Real interest rate is responded positively by variations in GDP. In addition, domestic credit as a percentage of GDP is significantly affected by GDP and exchange rate.

Keywords: financial development, economic growth, Egypt. 


\section{Introduction}

When considering economic growth theories, Solow model considered the most well known economic model to investigate this issue. This model which developed in the late of 1950s states that when the national economy attains its equilibrium level of output, growth rate of population and technology are the only determinants of economic growth (Valickova, 2012).

Other models emerged and criticized the theory in that, the Robert Solow theory managed to explain only small part of economic growth of a national economy, and there are more than this two determinants of output growth. With time, other models involving more than two determinants' such as, human capital accumulation, technology, propensity to save, and growth rate, were developed. However, these theoretical models neglected the level of country's financial development as important determinant, that is due to its' nature of complexity (Sindano, 2009 and Valickova, 2012).

Finance has been linked primarily with production process, regarding capital as an important input factor. Growth theory assumes that the interest rate plays the main role in equilibrating an economy's savings and investment. According to the neo-classical Golden Rule, the optimal growth path is equal to the real interest rate (Michael Thiel, 2001).

The link between financial development and economic growth has been examined by numerous empirical studies and it is well recognized that, financial sector development is essential for supporting economic growth (Hussain 2012).

It encourages capital accumulation and improves productivity which leads to increase economic growth through the functions practiced by the financial system such as, channeling funds from savers to investors, 
allocating capital, evaluation and monitoring borrowers through either effects of capital accumulation (rate of investment) and technological innovation.

Consequently, many studies have been undertaken attempting to answer two related questions, correlation and the direction of causality between financial development and economic growth. There is general agreement among economists about correlation but, the direction of causality between financial development and economic growth has remained debated matter and central question being whether financial development causes economic growth or economic growth causes financial sector development. (Aknilo et.al, 2010).

The link between finance and economic growth may run through various transmission channels. As AK model, a very simple growth model, illustrates that there are three important connections between financial variables (capital, savings, and productivities) and economic activity.

Many empirical researches showed interest in examining the finance growth nexus in recent years. Paper by (King and Levine, 1993) provided the starting point for intensified research, which received a major support by the construction of the financial structure database compiled for the World Bank by Beck et.al.

It is surprising to notice that, in most of the time studies undertaken largely concentrated in Latin America, Asia and advanced economies with insufficient coverage on the Middle East including Egypt.

In addition, there is a need to test the effect of financial variables which were used as an important tool in Egypt during the period of study to realize the effects of some important events such as the adoption of the program of structural reform in 1991, the Financial and Monetary Reform Program in 2003, and at last the three - years Extended Fund Facility in 
August 11, 2016 targeting to comprehensive economic reform program to restore macroeconomic stability and support strong, sustainable and job-rich growth, and to improve the functioning of the foreign exchange markets, bring down the budget deficit and government debt, and to raise growth and create jobs.

Therefore, this paper explores the relationship between GDP and selected financial variables based on Vector Error Correction Model (VECM). The results of this study can be summarized as following: GDP is negatively affected by both the real interest rate and the real exchange rate. Real interest rate is responded positively by variations in GDP. In addition, domestic credit as a percentage of GDP is significantly affected by GDP and exchange rate.

The study is structured as follows: In the next section, the literature review on the link between financial economic and economic growth are designed. In section 3, we designed financial development review of Egypt. Further section 4 includes data and methodology. Section 5 outlines empirical results. The paper ends with section 6 Conclusion.

\section{Literature review}

Investigating a vast literature in the field, we found several interdependencies between these factors, which make it difficult to establish and isolate the causal relation between economic growth and capital market development. The financial development role in economic growth considered as the most recent debated issue especially after the outbreak of the recent global financial crisis and the European debt crisis.

The relationship between financial development and economic growth is a controversial issue. Some studies consider financial development an important factor of economic growth (Schumpeter, 1934; Goldsmith, 1969; 
McKinnon, 1973; Shaw, 1973; King and Levine (1993), (Schumpeter, 1934) found out that banking sector is an engine of economic growth. Some other studies considered financial development as only a minor growth factor (Robinson, 1952; Lucas, 1988), (Lucas, 1988) proved that the role of finance has been overstated.

Summary of the theoretical literature suggests that there are four possibilities regarding the causal relationship between financial development and economic growth (Apergis et.al., 2007).

The first, called supply-leading response hypothesis, argues that financial development causes economic growth (Schumpeter, 1911, McKinnon, 1973; Shaw, 1973). (Goldsmith's paper, 1969), this hypothesis was the first to prove the existence of supply-leading response of financial development on GDP per capita. (King and Levine, 1993) used mostly monetary indicators and measures of the importance of banking institutions and found a significant positive relationship between some financial development indicators and GDP per capita growth. (Levine and Zervos, 1996) found a positive relation between some market development and GDP per capita growth. (Levine et.al., 2000) found evidence proves that development of financial elements accelerate growth. (Égert et.al., 2007; Backé et al., 2007)argued that there is a positive relationship between financial development and per capita income in the transition economies.

Fink et al. (2005), using a sample of 33 countries found that financial development has positive growth effects in the short run rather than in the long run. (Fink et al., 2008) argued the impact of the credit, bond and stock in nine EU-accession countries over the transition years (1996-2000), which found out that financial market elements except stock markets contributed to economic growth in the transition economies. In last decade study (Bonin and 
Watchel, 2003) found out significant impact of financial intermediaries on economic growth. We conclude that this view has been supported theoretically and empirically by a large number of studies.

The second hypothesis called demand-following response hypothesis posits that economic growth causes financial development. It argues that the development of the real sector stimulates demand for financial services that are passively met by the introduction of new financial institutions (Odhiambo, 2010).This view has been empirically confirmed by studies such as (Al-Yousif, 2002), (Ang and McKibbin, 2007), (Agbetsiafa, 2003), and (Waqabaca, 2004).

Odhiambo (2007) studied three Sub-Saharan African countries, where found evidence in support of demand-following hypothesis in Kenya and South Africa,he found also evidence in support of supply-leading hypothesis in Tanzania. (Baliamoune-Lutz, 2008) also found mixed results for North African countries. In the opinion of Kuznets (1955) financial markets begin to grow the economy becomes matured.

The third hypothesis is the mutual impact which argues that there is a bi-directional causal relationship between finance and growth (Demetriades and Hussein, 1996; and Greenwood and Smith, 1997). (Shan et al., 2001) show the bidirectional causality in five countries and one-way causality from growth to finance in three others when studying nine OECD countries and China.(Blanco, 2009) found two-way causality for the middle income countries with stronger rule of law and creditor rights of 18 Latin America countries. (Greenwood and Jovanovic, 1990) model the bidirectional interactions between finance and growth and emphasized the two-way causality between them. 
The fourth hypothesis is no-causal relationship hypothesis which argues that there is no causal relationship between financial development and economic growth (Graff, 1999; Lucas 1988). A number of recent empirical studies have reported a non-linear relationship between financial development and economic growth in developed and developing countries. For instance, (Deidda and Fattouh, 2002), (Jude, 2010) apply regression approach which showed no existence of effect of finance on economic growth.

In support of this notion, (Rousseau and Wachtel 2001) reported that in high inflation countries the effects of finance on growth weaken. This has been confirmed by (Rioja and Valev 2004) who studied 74 countries at different stages of development, employing Generalized Method of Moments (GMM) estimation. He also concluded that the evidence of an influence of financial development upon economic growth is highly dependent on the level of development of the financial sector of a particular country or group of countries.

It is obvious from this review of the literature that the nature of the relationship between financial development and economic growth is still an open question in both developed and developing countries.

Concerning Egypt few studies have tested the relationship between financial development and economic growth.(Suleiman Abu bader and Aamer S. Abuqarn, 2005) examined the causal relationship between financial development and economic growth in Egypt during the period (1960-2001)by applying Granger causality test using the Co-integration and Vector Error Correction (VEC) methodology, they used the ratio of money stock to nominal GDP, ratio of money stock minus currency to GDP, and the ratio of bank credit to the private sector to nominal GDP to measure the financial 
development. The findings suggested that financial development explained the economic reforms during that period.

Bolbol et.al. (2005) argued the financial market in Egypt the during the period (1974-2002), on Total Factor Productivity (TFP) and GDP per capita, based on growth accounting framework of the Cobb-Douglas production functions. The results show that bank-based indicators have a negative effect on TFP, whereas market-based indicators have positive effect.

(Mona Kamal, 2013) used Vector-Auto Regression (VAR) to estimate the causality between the banking sector development and economic growth during the period from (1988-2012) in Egypt. The study used both money and quasi money (M2) and domestic credit to private sector as a percentage of GDP to measure banking sector development. The findings suggested that there is no significant relationship between bank sector's financial development and stock market development with economic growth.

From this review of the literatures, we can see that the underlying relationship between GDP and financial development in Egypt is not completely formalized yet. In addition, there is a need to test the effect of other financial variables. Moreover, the effect of some important events such as the program of structural reform, financial and monetary reform, and 25 January revolution should be examined as well.

\section{Review of financial development in Egypt}

The financial development Report 2012(World Economic Forum) defined financial development as the factors, policies, and institutions that lead to effective financial intermediation and markets, as well as deep and broad access to capital and financial services. The Financial Development Report 2012 provides a Score and rank for the breadth, depth, and efficiency of 62 of the world's leading financial systems and capital markets according 
to factors that contribute to the long-term development of financial systems. These factors namely are institutional environment, business environment, financial stability, banking financial services, non-banking financial, financial markets, and financial access.

This section discusses the financial reforms occurred during the period of the study(1975-2016). (Figure 1) shows the development in GDP, real interest and exchange rate in Egypt during the period (1985-2016). By dividing this period into three phases, the first one (1990-1996) is Egypt's Economic Reform and Structural Adjustment Program (ERSAP), the second one (1997-2005)is the Transitional phase, and the last one is towards inflation targeting phase (2006-2010).

ERSAP aimed at realizing improvements in the growth rate of GDP through such as trade liberalization policies, the improvement of money and capital markets, and the establishment of a free pricing system. The IMF monetary policy recommendations revolved around setting a ceiling on net domestic credit of the Central Bank of Egypt (CBE) not the money supply of the monetary base (Mussa and Savastano, 1999).

One of the major difficulties that faced the monetary authority while applying these recommendations was promoting sharp reductions in level of net domestic credit that will push up level of interest rate, where the real interest rose from $(0.23 \%)$ during the period (1975-1985) to around (2\%) during the period (1986-1996) as shown in (Figure2).

Starting 2002, inflation development in Egypt was subject to unexplained variations in reaction to successive currency devaluation in the exchange rate. The Central Bank of Egypt announced in January 2005 the intention to adopt inflation targeting (IT) as a new monetary policy regime (Sherif Maher Hassan, 2012). 
Figure (1).Trend of Real GDP of Egypt in billion Egyptian pounds

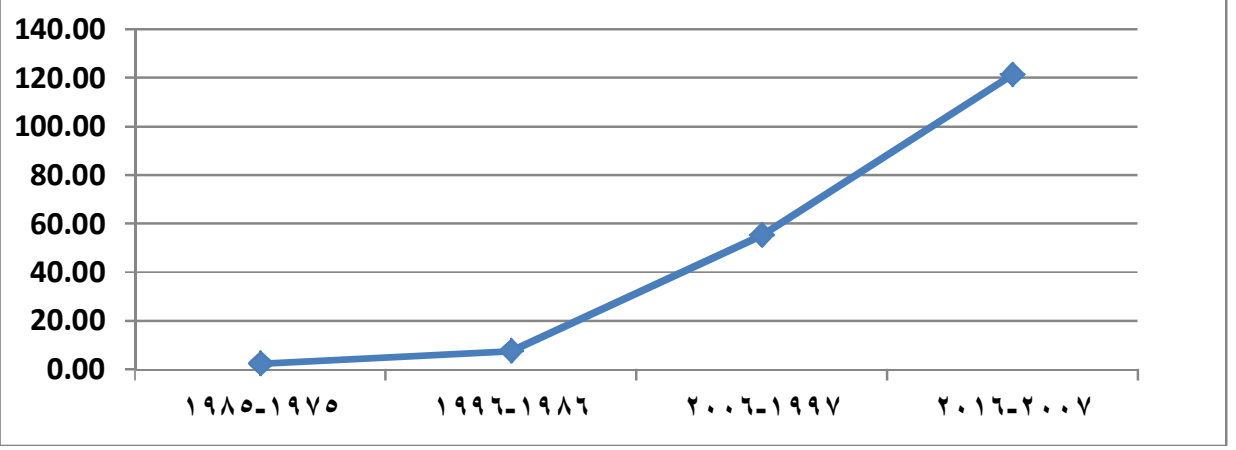

Figure (2). Trend of Real interest rate of Egypt

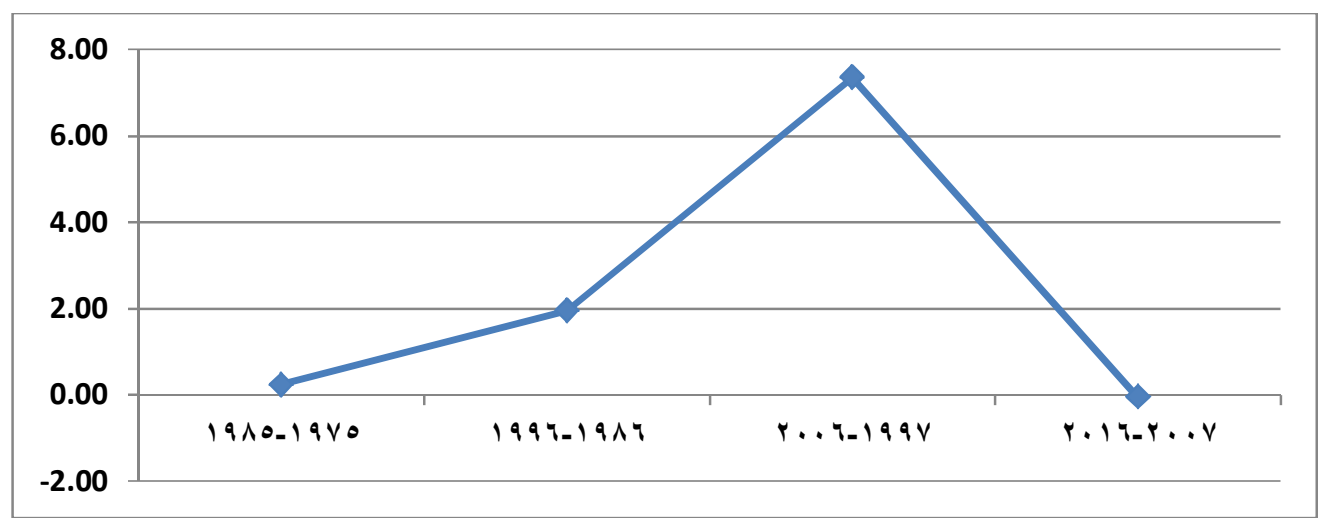

Figure (3). Trend of Real Exchange rate of Egypt

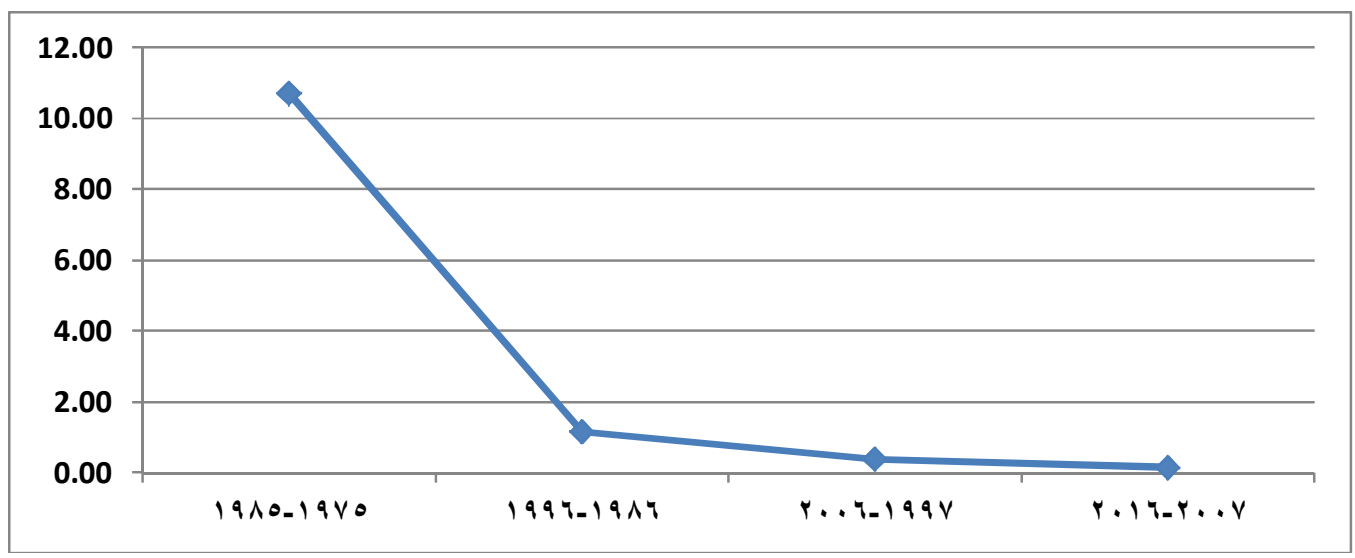




\section{Low exchange rate means depreciation.}

During the transitional period (1997-2005) the CBE has continually focused on achieving two principal objectives, price stability and exchange rate stability (MMZ, 2007). The CBE liberalized interest rate on loans and deposits, where real interest was raised from 1.95\% during (1986-1996) to 7.35\% during (1997-2006) as shown in figure 2. At the beginning of 1990s, Egypt officially implemented managed float regime, where exchange rate depreciated from \$1.16during (1986-1996) to 0.39 during (1997-2006) as shown in figure 3 , resulted in highly stable appreciated exchange rate for the Egyptian pound against US \$. Although IMF asked for 20-30\% currency devaluation of the exchange rate, Egyptian government refused to avoid inflation. Where, the real GDP increased from around 7.33 billion Egyptian pounds to around 55 billion as shown in Figure 1.

During the third period (2005-2010) ECB put in place an inflation targeting framework (Presidential Decree No. 17, 2005). The Coordinating Council on Monetary Policy was established in 2005, to ensure that government policies are consistent with the objectives of monetary policy. Egypt officially implemented a managed float regime, with the exchange rate acting as a nominal anchor for monetary policy. This resulted in a highly stable exchange rate for the Egyptian pound against the US dollar. ECB implemented significant devaluations of the Egyptian pound in 2001 and 2002, then in 2003, where the pound depreciated and lost $50 \%$ of its value, raised to 7.53 during (2007-2016), and inflation rate rose to $18 \%$ in 2004 (Hassan, 2003).

After 2011the revolution, Egypt has tried to return to political stability by accomplishing two main milestones of the political roadmap adopted in July 2013, and the ratification of the new constitution in January 2014. This 
political stability provided the government with the right opportunity to tackle the country's economic constraints, and to launch far-reaching structural reforms.

The Egyptian authorities have developed a homegrown economic program, which will be supported under the IMF's three-year Extended Fund Facility (EFF) in the amount of (422 percent of quota or about $\$ 12$ billion), to address longstanding challenges in the Egyptian economy. Include: a balance of payments problem overvalued exchange rate, and foreign exchange shortages; large budget deficits that led to rising public debt; and low growth rate with high unemployment.

Monetary policy framework during the program will rely on "money targeting". The Program aims to bring inflation to mid-single digits over the medium term (headline inflation was 23.3 percent in December).Central bank maintains short-term interest rates at levels that ensure tight liquidity conditions. CBE lift $\$ 100,000$ limit on transfers abroad by individuals, as

well as the $\$ 50,000$ cap on cash deposits for importing non-priority goods, by June 30 of 2017.

Moreover, during the program, IMF and CBE has devaluated the Egyptian pound by applying liberalized exchange rate regime and tight monetary policy, toward restoring confidence in national economy to anchor inflation expectations and allow accumulation of foreign exchange reserves.

\section{Data and the Methodology}

\subsection{Data}

Data include the Real Gross Domestic Products (GDP) with three other financial variables: the domestic credit as ratio of GDP, real interest rate, real exchange rate. In addition to, total capital accumulation as a ratio of GDP which is a macroeconomic variable related to physical assets required to 
investment and supporting GDP. The study covered the period 1975-2016. The choice of the sample period is executed for two reasons: (1) the sample period is long enough to explore the underlying relationship, and (2) the availability of data for relevant variables. All data are captured from the annual World Bank database. World development indicators

\subsection{The Methodology}

This study utilizes Error Correction Methodology (Banerjee, et. al 1993; Engle and Granger 1987, Johansen 1988; Johansen, and Juselius 1990). The multivariate Co-integration Model is based on the Error Correction Representation given by:

$$
\Delta Y_{t}=\mu+\sum_{i=1}^{k-1} \Gamma_{i} \Delta Y_{t-i}+\Pi Y_{t-1}+\Phi Z+\varepsilon_{t}
$$

Where $Y_{t}$ is a vector of $\mathrm{k}$ variables, $\Gamma$ and $\Pi$ indicating coefficient matrices, $\mu$ is a vector of intercepts or constant terms, $\Delta$ is a difference operator. $\Pi$ is coefficient matrix which captures effects over the long run and it is known as impact matrix. Moreover, $Z$ represents included exogenous variables that we added to measure effects of important recent events on the underlying relationship and $\Phi$ indicates coefficients associated included exogenous variables. Those exogenous variables are augmented inside the model to test effects of some recent important events on the underlying relationship. These events are the structural reform program in 1991, the financial reforms over 2003 and 2004, and finally the impact of 25 January revolution. Each one of these events is represented in the form of dummy variable as 0 from the beginning till the data of the event and 1 otherwise. 


\subsection{Testing Non-Stationary}

When dealing with time series analysis, non-stationary is one of the key characteristic that should be explored. When specific series is nonstationary this means that its mean and its variance are variant over time. Thus, results might be inappropriate for generalizing future recommendations about the underlying relationship. Classical regression analysis requires all included variables to be stationary. Several tests of unit root test or nonstationary tests might be utilized. For this purpose, this study uses the Augmented Dickey-Fuller (ADF) test. As the null hypothesis is that the underlying series has unit root and in the case of rejection null hypothesis this means the series is stationary.

\subsection{Testing For Co-integration}

In case of non-stationary of included data series, we should look at the existence of the long run relationship or Co-integration between those variables. Two main approaches usually are used to check for the Cointegration. One is Engle and Granger test (1987) and the other is Johansen multivariate Co-integration test (1988). In this study, as we have a multivariate model, we utilize the second approach which based on Vector Auto regression (VAR).

In regard of Johansen multivariate method, it based on the trace and the maximum value test. Where, the null hypothesis is that $\mathrm{r}=0$; there is no Cointegration relation, against $r>0$ or at least one Co-integration vector is exist. In case there are $\mathrm{k}$ variables included in the examined relationship, there are maximum (k-1) Co-integrated vectors.

\subsection{Granger Causality Test}

Granger causality method is used for testing whether specific variable $\mathrm{X}$ are causing another variable $Y$ or not (Granger, 1969). It tests whether X can help in predicting $\mathrm{Y}$ or not. In other words, whether past values of $\mathrm{X}$ are 
significant for forecasting $\mathrm{Y}$, if this is the case then $\mathrm{X}$ causes $\mathrm{Y}$. The null hypothesis for Granger causality test is that $\mathrm{X}$ does not cause $\mathrm{Y}$. This is against the alternative one that $\mathrm{X}$ causes $\mathrm{Y}$. We have two kinds of causality: unidirectional and bidirectional causality. The former causality type is applied when one of the variables $\mathrm{X}$ cause the another variable, say $\mathrm{Y}$, however this variable $\mathrm{Y}$ does not cause $\mathrm{X}$. The later causality applicable when each variable significantly cause the another variable. We will conduct causality test based on the estimated VECM. We have conducted multivariate Block Exogeneity Wald Tests in order to study the direction of causality between the included variables. In context of this test each of the endogenous variables will be considered as an exogenous one. Then, the Wald test (chisquare) test is conducted to test in what extent the lagged of each exogenous variable and the lagged of all other variables are significant.

\section{Empirical Results}

The first step, stationary is checked for different series. The following tables represent the outcomes of statistical analysis according to date derived from world bank, world development indicators 2017.

Table (1) presents unit root test results based on Augment Dickey Fuller test. The last two columns show that all variables are stationary in the first difference.

\section{Table(1) Unit root test results for different series}

\begin{tabular}{|l|l|l|l|l|}
\hline & \multicolumn{2}{|c|}{ Level } & \multicolumn{2}{c|}{ First Difference } \\
\hline Variables & Statistic & Prob. & Statistic & Prob. \\
\hline GDP & $-\mathbf{0 . 9 9 7 8}$ & $\mathbf{0 . 9 3 1 4}$ & $-\mathbf{4 . 9 5 1}$ & $\mathbf{0 . 0 0 1 4}$ \\
\hline DCR & -1.7752 & $\mathbf{0 . 6 9 7 4}$ & $-\mathbf{2 . 4 7 4 4}$ & $\mathbf{0 . 0 1 4 9}$ \\
\hline RI & -2.1911 & 0.4698 & -3.04875 & 0.0037 \\
\hline RX & -1.0488 & 0.2605 & -10.656 & 0.0000 \\
\hline WCGDP & $-\mathbf{3 . 2 0 3 5 7}$ & $\mathbf{0 . 0 9 8 2}$ & $-\mathbf{7 . 7 6 5 7 9}$ & $\mathbf{0 . 0 0 0 0}$ \\
\hline
\end{tabular}


DCR is domestic credit as a ratio of GDP, Ri is a real interest rate, RX is real exchange rate, and WCGDP is the total capital accumulation as a ratio of GDP.

Based on the unit root test results, the model of Vector Error Correction Model (VECM) is the most appropriate form of modeling the underlying relationship. In order to implement the VECM approach, we should firstly test for the existence of the long run relationship between different series. Table (2) shows that at least two equilibrium vectors exist for the underlying relationship. Thus, the VECM can be estimated. Table (3) gives evidence that the optimal lag selection for the VECM is two lags ${ }^{1}$. Further, Figure (4) shows that estimation of VECM with three lags is stable as all the inverse roots are either inside or on the circle.

Table (2). Unrestricted Co-integration Rank Test (Trace)

\begin{tabular}{|l|l|l|l|l|}
\hline & \multicolumn{1}{|c|}{ Eigen value } & $\begin{array}{c}\text { Trace } \\
\text { Statistic }\end{array}$ & $\begin{array}{c}\text { 0.05 } \\
\text { Critical Value }\end{array}$ & Prob. \\
\hline None ${ }^{*}$ & $\mathbf{0 . 6 4 6 3 7 5}$ & $\mathbf{9 2 . 4 3 5 5 3}$ & $\mathbf{6 9 . 8 1 8 8 9}$ & $\mathbf{0 . 0 0 0 3}$ \\
\hline At most 1 & $\mathbf{0 . 5 2 3 1 5 0}$ & $\mathbf{5 3 . 9 7 3 3 2}$ & 47.85613 & $\mathbf{0 . 0 1 1 9}$ \\
\hline At most 2 & $\mathbf{0 . 3 5 3 6 5 7}$ & $\mathbf{2 6 . 5 7 2 8 2}$ & 29.79707 & $\mathbf{0 . 1 1 2 5}$ \\
\hline At most 3 & $\mathbf{0 . 1 7 7 3 4 8}$ & $\mathbf{1 0 . 4 2 5 0 8}$ & $\mathbf{1 5 . 4 9 4 7 1}$ & $\mathbf{0 . 2 4 9 4}$ \\
\hline At most 4 & $\mathbf{0 . 0 8 2 8 9 9}$ & $\mathbf{3 . 2 0 1 8 8 9}$ & $\mathbf{3 . 8 4 1 4 6 6}$ & $\mathbf{0 . 0 7 3 5}$ \\
\hline
\end{tabular}

Table (3). VEC Lag Exclusion Wald Tests

\begin{tabular}{|l|l|}
\hline & Joint \\
\hline Lag 1 & $\mathbf{1 7 6 . 3 6 5 5}$ \\
& {$[0.000]$} \\
\hline Lag 2 & 92.59110 \\
& {$[0.000]$} \\
\hline
\end{tabular}

1 The test is conducted for one and two lags because the availability if data. 
Figure (4) Inverse roots for characteristic polynomial

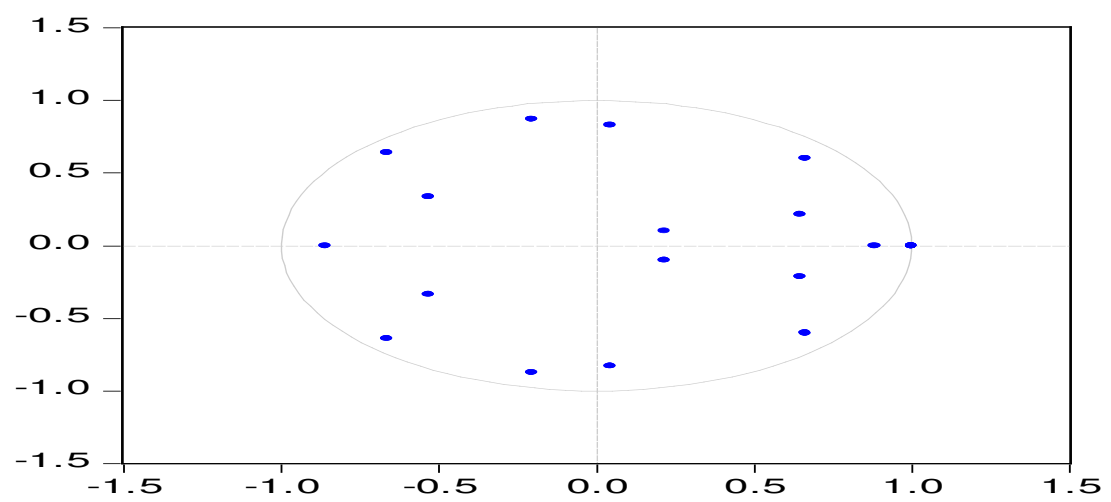

Our analysis will be based on impulse response functions, variance decomposition analysis and multivariate Granger causality. Figure (5) presents results of impulse response functions for the included variables as following:

1. GDP positively responses to one standard deviation of the total capital accumulation and negatively to each real interest rate and real exchange rate. This means that stimulating of GDP requires that supporting capital accumulation in the economy and controlling the huge variation in exchange rate and interest rate.

2. Real exchange rate responses positively to one standard deviation in each of GDP and itself. In addition, it is affected negatively by the private credit ratio to the total credit. This implies that high levels of real production could help in supporting the national currency.

3. Real interest rate responses positively to GDP and the ratio of total capital accumulation. This means encouraging of real interest rate which is required for improving investment climate in the economy requires higher levels of growth in the domestic production and increasing the capital accumulation in the economy.

4. Total capital accumulation as a ratio in GDP responses positively to one standard deviation in GDP and also to domestic real interest rate. 
However, it responses negatively to each real exchange rate. The last result indicates that currency devaluation of the Egyptian pound affected negatively the ratio of capital accumulation. However, the capital accumulation affected positively by positive variations in GDP. In addition, Domestic credit as a ratio of GDP responses positively to one standard deviation in real interest rate.

Tables from (4) to (8) depict the variance decomposition for the included variables. Table (4) shows that the variance of GDP is mainly explained by its own variations for the first and the second lags. However, it is explained with the variations in the WCGDP with its own past over the third lag. From the fourth lag the variations of GDP are explained by real interest rate, exchange rate with its lag. Table (5) depicts that variations of exchange rate is mainly explained the variation of capital accumulation, domestic credit as percentage of GDP, its lag and GDP respectively. Table (6) shows that the variation of real interest rate is mainly explained by GDP and the capital accumulation. This confirms the argument that controlling of real interest rate which is an essential for investment in any country requires stimulating the real production and the capital accumulation. Table (7) shows that variations in capital accumulation as a percentage in GDP is mainly explained by the variations of its lag and exchange rate. This confirms the statement that controlling of exchange rate variations is essential for enforcing capital accumulation and then real production in the economy. Table ( 8 ) states that variations in the domestic credit as a percentage of GDP is mainly explained by the variations of exchange rate, GDP, the total capital accumulation as a percentage in GDP. This clarifies that controlling the instabilities and variations of the domestic credit requires controlling the huge variations in exchange rate and also supporting the real production in Egypt. 


\section{Figure (5) Impulse response function for included variables}
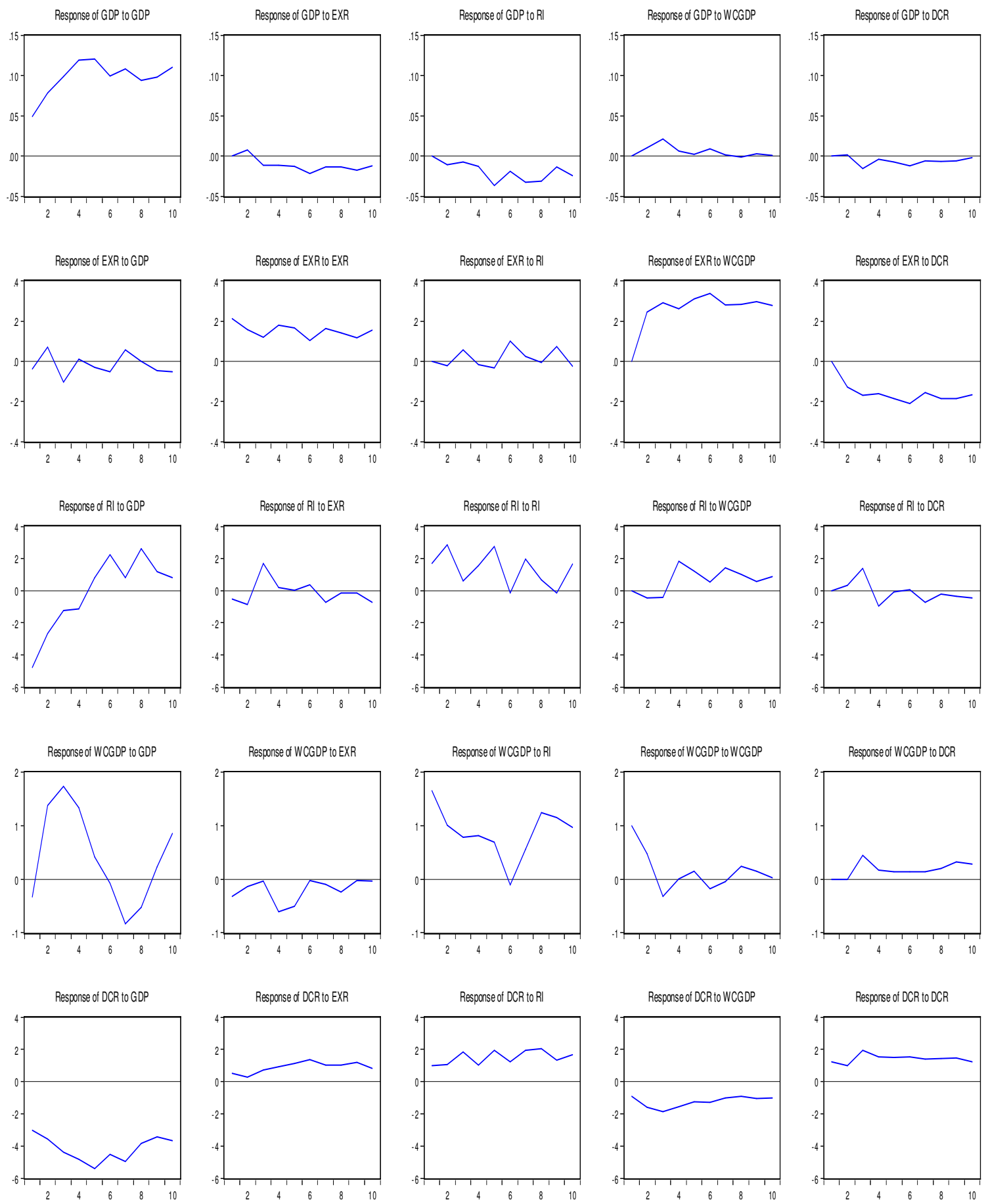
Table (4) Variance decomposition of GDP

\begin{tabular}{|c|c|c|c|c|c|}
\hline & GDP & EXR & RI & WCGDP & DCR \\
\hline 1 & $\mathbf{1 0 0 . 0 0 0 0}$ & $\mathbf{0 . 0 0 0 0 0 0}$ & $\mathbf{0 . 0 0 0 0 0 0}$ & $\mathbf{0 . 0 0 0 0 0 0}$ & $\mathbf{0 . 0 0 0 0 0 0}$ \\
\hline 2 & $\mathbf{9 6 . 8 1 0 7 9}$ & $\mathbf{0 . 6 4 4 6 5 7}$ & $\mathbf{1 . 3 5 9 7 9 8}$ & $\mathbf{1 . 1 6 6 6 3 8}$ & $\mathbf{0 . 0 1 8 1 1 3}$ \\
\hline 3 & $\mathbf{9 4 . 0 3 8 7 7}$ & $\mathbf{0 . 9 9 0 9 8 9}$ & $\mathbf{0 . 9 3 1 4 0 7}$ & $\mathbf{2 . 7 8 2 8 4 5}$ & $\mathbf{1 . 2 5 5 9 8 9}$ \\
\hline $\mathbf{4}$ & $\mathbf{9 5 . 5 7 4 7 6}$ & $\mathbf{0 . 9 4 4 8 8 4}$ & $\mathbf{1 . 0 1 2 5 9 8}$ & $\mathbf{1 . 6 8 8 7 8 8}$ & $\mathbf{0 . 7 7 8 9 6 7}$ \\
\hline $\mathbf{5}$ & $\mathbf{9 3 . 8 3 8 8 4}$ & $\mathbf{0 . 9 8 7 3 0 8}$ & $\mathbf{3 . 3 8 5 4 2 5}$ & $\mathbf{1 . 1 5 7 4 4 2}$ & $\mathbf{0 . 6 3 0 9 8 7}$ \\
\hline $\mathbf{6}$ & $\mathbf{9 3 . 1 9 9 4 2}$ & $\mathbf{1 . 5 8 3 7 0 7}$ & $\mathbf{3 . 3 7 6 3 2 0}$ & $\mathbf{1 . 0 7 3 4 4 3}$ & $\mathbf{0 . 7 6 7 1 0 7}$ \\
\hline $\mathbf{7}$ & $\mathbf{9 2 . 6 7 3 1 5}$ & $\mathbf{1 . 5 4 3 0 0 0}$ & $\mathbf{4 . 2 1 3 1 5 0}$ & $\mathbf{0 . 8 8 8 3 3 3}$ & $\mathbf{0 . 6 8 2 3 7 1}$ \\
\hline $\mathbf{8}$ & $\mathbf{9 2 . 1 2 4 5 3}$ & $\mathbf{1 . 5 7 1 7 7 9}$ & $\mathbf{4 . 8 6 5 1 8 5}$ & $\mathbf{0 . 7 8 2 9 8 1}$ & $\mathbf{0 . 6 5 5 5 2 3}$ \\
\hline $\mathbf{9}$ & $\mathbf{9 2 . 4 0 4 6 8}$ & $\mathbf{1 . 7 3 5 0 2 2}$ & $\mathbf{4 . 5 2 5 8 8 3}$ & $\mathbf{0 . 7 0 6 9 4 5}$ & $\mathbf{0 . 6 2 7 4 7 1}$ \\
\hline 10 & $\mathbf{9 2 . 6 2 7 3 9}$ & $\mathbf{1 . 6 6 3 2 8 4}$ & $\mathbf{4 . 5 3 1 1 2 4}$ & $\mathbf{0 . 6 2 1 8 9 1}$ & $\mathbf{0 . 5 5 6 3 1 3}$ \\
\hline 11 & $\mathbf{9 2 . 6 9 9 9 8}$ & $\mathbf{1 . 6 8 1 9 0 0}$ & $\mathbf{4 . 5 2 4 2 6 4}$ & $\mathbf{0 . 5 5 9 0 9 5}$ & $\mathbf{0 . 5 3 4 7 6 6}$ \\
\hline 12 & $\mathbf{9 2 . 8 6 5 3 2}$ & $\mathbf{1 . 6 8 8 2 3 8}$ & $\mathbf{4 . 4 4 4 5 7 6}$ & $\mathbf{0 . 5 0 4 3 1 5}$ & $\mathbf{0 . 4 9 7 5 5 3}$ \\
\hline
\end{tabular}

Table (5) Variance decomposition of Exchange rate

\begin{tabular}{|c|c|c|c|c|c|}
\hline & GDP & EXR & RI & WCGDP & DCR \\
\hline 1 & $\mathbf{3 . 0 6 4 5 1 6}$ & $\mathbf{9 6 . 9 3 5 4 8}$ & $\mathbf{0 . 0 0 0 0 0 0}$ & $\mathbf{0 . 0 0 0 0 0 0}$ & $\mathbf{0 . 0 0 0 0 0 0}$ \\
\hline 2 & $\mathbf{4 . 1 9 2 0 1 2}$ & $\mathbf{4 5 . 5 3 9 0 5}$ & $\mathbf{0 . 2 7 7 3 9 2}$ & $\mathbf{3 9 . 0 8 8 2 1}$ & $\mathbf{1 0 . 9 0 3 3 3}$ \\
\hline 3 & $\mathbf{5 . 7 6 6 2 0 5}$ & $\mathbf{2 8 . 4 9 8 5 1}$ & $\mathbf{1 . 2 5 9 1 1 9}$ & $\mathbf{4 9 . 0 0 5 3 4}$ & $\mathbf{1 5 . 4 7 0 8 3}$ \\
\hline $\mathbf{4}$ & $\mathbf{4 . 0 4 8 0 5 2}$ & $\mathbf{2 7 . 5 7 0 7 1}$ & $\mathbf{0 . 9 6 1 7 0 6}$ & $\mathbf{5 0 . 4 8 9 2 9}$ & $\mathbf{1 6 . 9 3 0 2 4}$ \\
\hline $\mathbf{5}$ & $\mathbf{3 . 0 8 6 4 7 9}$ & $\mathbf{2 4 . 7 3 2 4 9}$ & $\mathbf{0 . 8 8 9 2 4 4}$ & $\mathbf{5 3 . 0 6 3 8 5}$ & $\mathbf{1 8 . 2 2 7 9 4}$ \\
\hline $\mathbf{6}$ & $\mathbf{2 . 7 0 3 8 9 1}$ & $\mathbf{2 0 . 2 3 2 4 1}$ & $\mathbf{1 . 9 7 3 1 5 0}$ & $\mathbf{5 5 . 4 1 1 7 1}$ & $\mathbf{1 9 . 6 7 8 8 4}$ \\
\hline $\mathbf{7}$ & $\mathbf{2 . 6 5 9 1 9 6}$ & $\mathbf{2 0 . 1 4 1 4 8}$ & $\mathbf{1 . 7 4 3 5 2 3}$ & $\mathbf{5 6 . 0 1 3 6 8}$ & $\mathbf{1 9 . 4 4 2 1 2}$ \\
\hline $\mathbf{8}$ & $\mathbf{2 . 3 1 3 2 5 3}$ & $\mathbf{1 9 . 4 7 5 2 9}$ & $\mathbf{1 . 5 2 0 5 2 5}$ & $\mathbf{5 6 . 4 6 4 9 9}$ & $\mathbf{2 0 . 2 2 5 9 4}$ \\
\hline $\mathbf{9}$ & $\mathbf{2 . 2 0 5 7 5 2}$ & $\mathbf{1 8 . 2 3 6 8 5}$ & $\mathbf{1 . 7 7 9 9 7 2}$ & $\mathbf{5 7 . 0 7 3 5 2}$ & $\mathbf{2 0 . 7 0 3 9 0}$ \\
\hline 10 & $\mathbf{2 . 1 9 3 0 9 2}$ & $\mathbf{1 8 . 2 5 5 5 5}$ & $\mathbf{1 . 6 4 4 1 2 2}$ & $\mathbf{5 7 . 1 4 5 8 7}$ & $\mathbf{2 0 . 7 6 1 3 7}$ \\
\hline 11 & $\mathbf{3 . 6 0 2 1 5 8}$ & $\mathbf{1 7 . 6 4 0 8 1}$ & $\mathbf{1 . 4 8 0 1 0 7}$ & $\mathbf{5 6 . 3 4 1 2 0}$ & $\mathbf{2 0 . 9 3 5 7 3}$ \\
\hline 12 & $\mathbf{4 . 1 9 5 2 8 7}$ & $\mathbf{1 7 . 4 0 2 9 2}$ & $\mathbf{1 . 5 3 0 1 1 0}$ & $\mathbf{5 6 . 1 1 5 7 6}$ & $\mathbf{2 0 . 7 5 5 9 3}$ \\
\hline
\end{tabular}

Table (6). Variance decomposition of Real interest rate

\begin{tabular}{|c|c|c|c|c|c|}
\hline & GDP & EXR & RI & WCGDP & DCR \\
\hline $\mathbf{1}$ & $\mathbf{8 7 . 9 1 7 1 9}$ & $\mathbf{1 . 1 1 1 3 0 2}$ & $\mathbf{1 0 . 9 7 1 5 1}$ & $\mathbf{0 . 0 0 0 0 0 0}$ & $\mathbf{0 . 0 0 0 0 0 0}$ \\
\hline $\mathbf{2}$ & $\mathbf{7 0 . 7 1 7 6 7}$ & $\mathbf{2 . 3 9 9 4 3 8}$ & $\mathbf{2 6 . 1 0 6 0 7}$ & $\mathbf{0 . 5 3 2 6 8 4}$ & $\mathbf{0 . 2 4 4 1 4 0}$ \\
\hline 3 & $\mathbf{6 4 . 0 1 8 4 0}$ & $\mathbf{7 . 8 3 7 9 6 2}$ & $\mathbf{2 3 . 3 1 1 9 9}$ & $\mathbf{0 . 7 9 7 9 9 5}$ & $\mathbf{4 . 0 3 3 6 5 6}$ \\
\hline $\mathbf{4}$ & $\mathbf{5 7 . 2 0 9 2 0}$ & $\mathbf{6 . 7 9 0 0 1 2}$ & $\mathbf{2 4 . 2 7 0 5 6}$ & $\mathbf{6 . 6 1 3 1 9 8}$ & $\mathbf{5 . 1 1 7 0 3 0}$ \\
\hline $\mathbf{5}$ & $\mathbf{4 9 . 8 5 0 9 6}$ & $\mathbf{5 . 8 0 4 7 0 6}$ & $\mathbf{3 2 . 0 1 6 4 3}$ & $\mathbf{7 . 9 4 6 6 5 8}$ & $\mathbf{4 . 3 8 1 2 4 4}$ \\
\hline $\mathbf{6}$ & $\mathbf{5 3 . 0 0 7 1 8}$ & $\mathbf{5 . 5 3 8 4 0 8}$ & $\mathbf{2 9 . 6 4 3 2 1}$ & $\mathbf{7 . 7 5 5 7 9 7}$ & $\mathbf{4 . 0 5 5 4 0 3}$ \\
\hline
\end{tabular}




\begin{tabular}{|c|c|c|c|c|c|}
\hline $\mathbf{7}$ & $\mathbf{4 8 . 7 3 0 0 7}$ & $\mathbf{5 . 6 9 0 2 0 3}$ & $\mathbf{3 1 . 6 4 2 6 5}$ & $\mathbf{9 . 6 0 3 1 1 0}$ & $\mathbf{4 . 3 3 3 9 7 1}$ \\
\hline $\mathbf{8}$ & $\mathbf{5 1 . 8 5 3 7 5}$ & $\mathbf{5 . 1 7 3 8 8 8}$ & $\mathbf{2 9 . 1 3 2 0 2}$ & $\mathbf{9 . 8 6 6 5 6 8}$ & $\mathbf{3 . 9 7 3 7 6 9}$ \\
\hline $\mathbf{9}$ & $\mathbf{5 2 . 2 9 4 7 9}$ & $\mathbf{5 . 0 8 7 6 4 7}$ & $\mathbf{2 8 . 5 4 0 3 6}$ & $\mathbf{1 0 . 0 3 6 3 0}$ & $\mathbf{4 . 0 4 0 9 0 6}$ \\
\hline 10 & $\mathbf{5 0 . 3 0 2 6 3}$ & $\mathbf{5 . 3 5 5 8 8 5}$ & $\mathbf{2 9 . 9 7 9 5 7}$ & $\mathbf{1 0 . 2 9 8 0 0}$ & $\mathbf{4 . 0 6 3 9 1 9}$ \\
\hline 11 & $\mathbf{5 1 . 3 0 4 1 6}$ & $\mathbf{5 . 1 6 7 8 6 3}$ & $\mathbf{2 9 . 1 6 5 1 6}$ & $\mathbf{1 0 . 4 4 6 5 7}$ & $\mathbf{3 . 9 1 6 2 5 0}$ \\
\hline 12 & $\mathbf{5 0 . 7 7 6 5 3}$ & $\mathbf{5 . 1 7 4 9 9 3}$ & $\mathbf{2 9 . 2 3 7 4 0}$ & $\mathbf{1 0 . 7 9 6 8 0}$ & $\mathbf{4 . 0 1 4 2 8 1}$ \\
\hline
\end{tabular}

Table (7). Variance decomposition of the capital accumulation as a percentage of GDP

\begin{tabular}{|c|c|c|c|c|c|}
\hline & GDP & EXR & $\mathbf{R I}$ & WCGDP & DCR \\
\hline 1 & 1.983705 & 2.848068 & 2.733619 & 69.49581 & 24.92250 \\
\hline 2 & 2.664036 & 28.39660 & 1.789776 & 52.81794 & 16.99359 \\
\hline 3 & 3.318169 & 45.54059 & 1.168857 & 39.58616 & 11.89793 \\
\hline 4 & 3.721064 & 49.00172 & 3.639481 & 36.26155 & 9.460939 \\
\hline 5 & 3.844545 & 47.02343 & 5.193227 & 37.10840 & 9.013732 \\
\hline 6 & 3.853630 & 46.84908 & 5.174074 & 37.02134 & 9.185305 \\
\hline 7 & 3.984944 & 48.14867 & 4.905681 & 36.57243 & 8.607268 \\
\hline 8 & 4.222696 & 44.40867 & 4.701390 & 41.12939 & 7.973050 \\
\hline 9 & 4.396569 & 41.23435 & 4.341521 & 44.77657 & 7.458248 \\
\hline 10 & 4.590482 & 41.29694 & 3.987921 & 45.49342 & 6.843646 \\
\hline 11 & 4.768629 & 41.65654 & 3.968018 & 45.57658 & 6.360823 \\
\hline 12 & 4.848693 & 41.18614 & 4.307994 & 45.86816 & 6.189941 \\
\hline
\end{tabular}

Table ( 8). Variance decomposition of DCR

\begin{tabular}{|c|c|c|c|c|c|}
\hline & GDP & EXR & RI & WCGDP & DCR \\
\hline 1 & $\mathbf{3 . 5 6 0 1 1 5}$ & $\mathbf{7 1 . 7 3 7 6 5}$ & $\mathbf{2 . 0 9 7 1 8 1}$ & $\mathbf{7 . 7 4 8 8 9 9}$ & $\mathbf{6 . 2 7 2 6 3 8}$ \\
\hline 2 & $\mathbf{5 . 4 8 3 0 1 9}$ & $\mathbf{7 2 . 2 2 5 4 7}$ & $\mathbf{1 . 1 4 7 9 7 9}$ & $\mathbf{7 . 0 1 2 9 2 3}$ & $\mathbf{1 1 . 1 3 2 9 0}$ \\
\hline 3 & $\mathbf{7 . 7 8 5 2 6 4}$ & $\mathbf{6 7 . 7 8 8 2 8}$ & $\mathbf{1 . 4 0 8 9 3 3}$ & $\mathbf{9 . 0 9 8 5 4 9}$ & $\mathbf{1 1 . 3 0 6 8 5}$ \\
\hline 4 & $\mathbf{9 . 5 2 0 2 3 8}$ & $\mathbf{7 0 . 9 8 1 6 9}$ & $\mathbf{1 . 9 2 8 9 1 1}$ & $\mathbf{7 . 3 0 1 7 7 0}$ & $\mathbf{1 0 . 2 1 2 3 2}$ \\
\hline $\mathbf{5}$ & 11.35622 & $\mathbf{7 2 . 6 2 0 2 4}$ & $\mathbf{2 . 3 6 1 4 8 5}$ & $\mathbf{8 . 1 1 1 2 3 1}$ & $\mathbf{8 . 4 2 2 1 5 7}$ \\
\hline $\mathbf{6}$ & 12.52109 & $\mathbf{7 2 . 7 0 8 0 1}$ & $\mathbf{3 . 1 2 9 2 2 0}$ & $\mathbf{7 . 6 5 6 1 9 6}$ & $\mathbf{7 . 9 8 8 7 7 8}$ \\
\hline 7 & 13.75633 & $\mathbf{7 3 . 2 4 0 6 0}$ & $\mathbf{3 . 1 5 6 6 3 4}$ & $\mathbf{8 . 3 6 3 8 6 4}$ & $\mathbf{7 . 1 5 6 0 6 9}$ \\
\hline $\mathbf{8}$ & 14.56704 & $\mathbf{7 2 . 2 8 9 9 2}$ & $\mathbf{3 . 3 2 5 8 7 6}$ & $\mathbf{9 . 4 3 7 7 3 4}$ & $\mathbf{6 . 7 8 0 0 3 8}$ \\
\hline $\mathbf{9}$ & $\mathbf{1 5 . 1 8 3 2 5}$ & $\mathbf{7 1 . 6 6 1 5 2}$ & $\mathbf{3 . 6 9 0 9 0 2}$ & $\mathbf{9 . 4 5 0 2 5 6}$ & $\mathbf{6 . 7 3 8 8 1 3}$ \\
\hline 10 & $\mathbf{1 5 . 8 1 6 7 4}$ & $\mathbf{7 1 . 4 5 4 0 7}$ & $\mathbf{3 . 6 7 5 9 3 5}$ & $\mathbf{9 . 8 2 4 4 0 7}$ & $\mathbf{6 . 6 3 2 3 0 6}$ \\
\hline 11 & 16.39688 & $\mathbf{7 1 . 0 8 4 6 5}$ & $\mathbf{3 . 7 2 8 6 2 1}$ & $\mathbf{9 . 9 5 8 5 5 6}$ & $\mathbf{6 . 6 2 9 8 0 1}$ \\
\hline 12 & 17.02109 & $\mathbf{7 1 . 3 9 0 1 3}$ & $\mathbf{3 . 7 5 7 2 6 6}$ & $\mathbf{9 . 6 9 7 5 1 6}$ & $\mathbf{6 . 5 8 0 4 5 6}$ \\
\hline
\end{tabular}


Table (9) depicts the multivariate granger causality based on block exogenity test. This table shows that:

- GDP is caused by real interest rate, total capital accumulation as a percentage of GDP, and all included financial variables together have a significant effect on GDP as a chi-square test statistic is $13.88,12.42$ and 25.03 respectively. This implies that we reject the null hypothesis which states the lagged coefficients for each of those variables is zero. However, the Chi-square statistic for exchange rate and domestic credit is not significant and then we failed to reject the null hypothesis that the coefficients of their lags are zero.

- Exchange rate is significantly affected by GDP, domestic credit as a percentage of GDP, all included variables together.

- Real interest rate is significantly caused by GDP, total capital accumulation as a percentage of GDP, and the summation of all included variables.

- Total capital accumulation as a percentage of GDP, exchange rate, real interest rate, domestic credit as a percentage of GDP and the summation of all variables together.

- Domestic credit as a percentage of GDP is significantly caused by GDP, real interest rate, and the summation of all included variables together.

In sum, multivariate Granger causality test imply that GDP is significantly affected by some of the financial variables and the included physical variable; (total capital accumulation as a percentage of GDP). However, all included financial variables are significantly caused by GDP. 
Table (9) VECM Granger Causality by using Block Exogeneity Wald Tests

\begin{tabular}{|c|c|c|c|c|c|c|c|c|c|c|}
\hline & \multicolumn{2}{|c|}{ D(GDP) } & \multicolumn{2}{c|}{ D(EXR) } & \multicolumn{2}{c|}{ D(RI) } & \multicolumn{2}{c|}{ D(WCGDP) } & \multicolumn{2}{c|}{ D(DCR) } \\
\hline & $\begin{array}{c}\text { Chi- } \\
\text { sq }\end{array}$ & Prob. & Chi-sq & Prob. & Chi-sq & Prob. & Chi-sq & Prob. & Chi-sq & Prob. \\
\hline D(GDP) & & & 14.509 & $\mathbf{0 . 0 0 0}$ & $\mathbf{1 4 . 0 7 2}$ & $\mathbf{0 . 0 0 0 9}$ & $\mathbf{1 9 . 6 7 8 3}$ & $\mathbf{0 . 0 0 0}$ & $\mathbf{6 . 2 0 5 9 7}$ & $\mathbf{0 . 0 4 4}$ \\
\hline D(EXR) & $\mathbf{2 . 5 3}$ & $\mathbf{0 . 2 8 1}$ & & & 4.202 & $\mathbf{0 . 1 2 2}$ & $\mathbf{6 . 3 8 5 2}$ & $\mathbf{0 . 0 4 1}$ & $\mathbf{0 . 5 3 8 4}$ & $\mathbf{0 . 7 6 4}$ \\
\hline D(RI) & $\mathbf{1 3 . 8 8}$ & $\mathbf{0 . 0 0 1}$ & $\mathbf{2 . 9 7 8 7}$ & $\mathbf{0 . 2 2 5}$ & & & $\mathbf{1 0 . 6 7 8}$ & $\mathbf{0 . 0 0 4}$ & $\mathbf{4 . 8 1 8}$ & $\mathbf{0 . 0 8 9}$ \\
\hline D(WCGDP) & $\mathbf{1 2 . 4}$ & $\mathbf{0 . 0 0 2}$ & $\mathbf{2 . 1 6 7 3 8 9}$ & $\mathbf{0 . 3 3 8 3}$ & $\mathbf{1 0 . 4 7 9 3 3}$ & $\mathbf{0 . 0 0 5 3}$ & & & 1.409 & $\mathbf{0 . 4 9 4}$ \\
\hline D(DCR) & $\mathbf{1 . 9 4 8}$ & $\mathbf{0 . 3 7 7}$ & $\mathbf{1 5 . 9 5 6 9 9}$ & $\mathbf{0 . 0 0 0 3}$ & $\mathbf{0 . 8 0 8 7 6 9}$ & $\mathbf{0 . 6 6 7 4}$ & $\mathbf{7 . 3 0 7 7 7 5}$ & $\mathbf{0 . 0 2 5 9}$ & & \\
\hline All & $\mathbf{2 5 . 0 3}$ & $\mathbf{0 . 0 0 1 5}$ & $\mathbf{4 5 . 0 3 0}$ & $\mathbf{0 . 0 0 0}$ & $\mathbf{3 7 . 5 6 0}$ & $\mathbf{0 . 0 0 0}$ & $\mathbf{2 7 . 7 1 3}$ & $\mathbf{0 . 0 0 0}$ & $\mathbf{1 6 . 0 3 9}$ & $\mathbf{0 . 0 4 1}$ \\
\hline
\end{tabular}

In order to explore the effects of the important events on GDP, we can capture their coefficients from the underlying VECM as in table (9), which can be summarized as following:

1. Structural Reforming Program in 1991 affected positively the real interest rate and the rationing of private credit to GDP. However, it affected negatively GDP.

2. Financial Reform started in 2003 and the beginning of 2004, affected positively the GDP and whole capital accumulation. It affected negatively the real interest rate and the exchange rate.

3. The 25 January revolution in 2011 , affected positively the exchange rate. This means the revolution contributed in increasing the depreciation values in the Egyptian currency.

Table (10) Estimates the Effect of Important Events on GDP

\begin{tabular}{|c|c|c|c|c|c|}
\hline & D(GDP) & D(EXR) & $\mathbf{D}(\mathbf{R I})$ & D(WCGDP) & D(DCR) \\
\hline SP & $\begin{array}{c}-0.083328 \\
(0.02688) \\
{[-3.10054]}\end{array}$ & $\begin{array}{c}\mathbf{0 . 1 3 9 1 5 2} \\
(\mathbf{0 . 1 6 7 2 7}) \\
{[0.83188]}\end{array}$ & $\begin{array}{c}6.904381 \\
(2.62819) \\
2.62705 \\
\end{array}$ & $\begin{array}{c}\mathbf{1 . 8 4 5 7 2 6} \\
(1.31867) \\
{[1.39969]}\end{array}$ & $\begin{array}{r}5.317719 \\
(1.90881) \\
{[2.78588]}\end{array}$ \\
\hline FS & $\begin{array}{c}\mathbf{0 . 0 8 5 0 3 0} \\
(\mathbf{0 . 0 4 1 4 3}) \\
{[2.05221]}\end{array}$ & $\begin{array}{r}-1.404805 \\
(0.25788) \\
{[-5.44743]}\end{array}$ & $\begin{array}{r}-9.207141 \\
(4.05186) \\
{[-2.27232]}\end{array}$ & $\begin{array}{c}5.306309 \\
(2.03298) \\
{[2.61011]}\end{array}$ & $\begin{array}{c}-5.265417 \\
(2.94280) \\
{[-1.78925]}\end{array}$ \\
\hline $\mathbf{R V}$ & 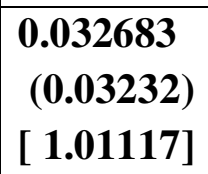 & $\begin{array}{c}\mathbf{0 . 4 8 1 6 8 9} \\
(0.20117) \\
{[2.39439]}\end{array}$ & $\begin{array}{r}-3.548701 \\
(3.16084) \\
{[-1.12271]}\end{array}$ & $\begin{array}{c}1.289254 \\
(1.58592) \\
{[0.81294]}\end{array}$ & $\begin{array}{c}2.650914 \\
(2.29567) \\
{[1.15475]}\end{array}$ \\
\hline Adj. R-squared & 0.587340 & 0.605198 & 0.602462 & 0.441232 & 0.445544 \\
\hline
\end{tabular}


SP refers to Structural Reform Program, FS refers to Financial Structure program and RV refers to the $25^{\text {th }}$ January 2011 Revelation.

\section{Conclusion}

The study explored the direction of causality between GDP and some selected financial variables. Results and recommendations can be summarised in the following points:

1. There is a huge decreasing in the level of real interest rate in the last 10 years resulted in high inflation.

2. We found a noticeable depreciation for the real value of Egyptian pound as a result of decreasing the nominal value of Egyptian pound and the increasing in the level of inflation for the last two decades.

3. The Co-integration test shows that there is a long run relationship between the real GDP and the included financial variables.

4. GDP is responses to one standard deviation real interest rate. This means that stimulating of GDP requires that controlling the huge variation in real interest rate. Similarly, Variance decomposition analysis shows that the variance of GDP is significantly explained by real interest rate. This might be interpreted through the investment channel. High interest rate means high costs for investors. So government should put restrictions on continues increases in interest rate level.

5. GDP negatively responses to one standard deviation real exchange rate. this is might has interpretation through the effect of increasing costs of imported raw materials and imported capital after increasing the exchange rate value. So, economic policies should cooperate together to overcome the problem of increasing the exchange rate 
level. This recommendation is consistent with the three-year extended arrangement under the Extended Fund Facility (EFF) program approved by (IMF), which focus on liberalization of the foreign exchange system to eliminate foreign exchange shortages and encourage investment and exports. Although this recommendation is contrary to the policy of the Central Bank of Egypt since in 2014/15, which aimed to increase interest rates to contain inflationary pressures, decreasing the interest rate would be effective to both GDP and the capital accumulation, as real interest rate is Granger caused by capital accumulation.

6. Exchange rate responses positively to variations in GDP, which provides the evidence that defending the value of national currency requires stimulating the growth of real production. In addition, variance decomposition analysis shows that a variation in exchange rate is significantly affected in variations of capital accumulation, domestic credit and GDP.

7. Real interest rate responses positively to variations in GDP and capital accumulation as a ratio of GDP, which implies that supporting the value of national currency requires stimulating the growth of real production. In addition, capital accumulation is essential for controlling real interest rate and investment.

8. Capital accumulation as a ratio of GDP is significantly affected by real exchange rate which supports the statement that controlling of exchange rate is essential for capital accumulation in the economy. Capital accumulation channel via the rate of gross domestic investments to GDP links financial development and economic growth in the short run, suggesting that long-term financial infrastructures that 
are necessary for successful promoting investments for sporting economic growth still remain weak in Egypt. These findings were in agreement with some previous studies and differed with other studies that dealt with the situation in Egypt. The study results agreed with the study of (Suleiman Abu bader and Aamer S. Abuqarn, 2005) in the effectiveness of the financial market on economic growth, although the different in the variables which measured the financial market. On the other hand, the study results differed with study of (Mona Kamal, 2013) which suggested no significant relationship between financial markets and economic growth. However, it should be clarified that the (Mona Kamal, 2013)'s study used different variables measuring financial market (quasi money, and domestic private credit as a percentage of GDP), where in this study other variable were used in measuring financial market (real interest rate, real exchange rate, and total capital accumulation as a ratio of GDP) which supposed that monetary tools could affect in money supply and private credit.

9. Domestic credit as a percentage of GDP is significantly affected GDP, exchange rate and the ration of capital accumulation from GD which implies that supporting real production and controlling huge variations of exchange rate is necessary for supporting domestic credit in the Egyptian economy.

In view of feedback effects, the study recommended that more efforts should be devoted to the deepening of financial sector by enhancing competition, improving business environment, investing in human capital (educations, training and health care). 


\section{References}

1. Abu-Bader, S. and Abu-Qarn, A. M. (2005). Financial Development and Economic Growth: time series evidence from Egypt, Discussion Paper No.05-14a

2. Abu-Bader, S. and Abu-Qarn, A. M. (2008). Financial Development and Economic Growth Empirical Evidence from MENA countries. Review of Development Economics 12.

3. Akinlo .A. and Egbetunde.T. (2010). Financial Development and Economic Growth: The Experience of 10 Sub-Saharan African Countries Revisited.

4. Agbetsiafa, D. K. (2003). The Finance Growth Nexus: Evidence from Sub-Saharan Africa. International Advances in Economic Research 9, 172-189.

5. Baliamoune-Lutz, (2008). Financial Development and Income. International Advances in Economic Research 14, 422 - 432.

6. Bolbol, A., Fatheldin, A., and Omran, M. (2005) 'Financial Development, Structure, and Economic Growth: The Case of Egypt, 1974-2002', Research in International Business and Finance, 19, pp.171-194

7. Bonin J., Wachtel P. (2003), "Financial Sector Development in Transition Economies: Lessons from the First Decade", Financial Markets, Institutions and Instruments 12 .

8. Brasoveanul L. O., Dragota V., Catarama D., Semenescu A. (2010) 'Correlations between Capital Market Development and Economic Growth: The Case of Romania', Journal of Applied

9. Égert B., Backé P., Zumer T. (2007), "Private-Sector Credit in Central and Eastern Europe: New (Over) Shooting Stars?", Comparative Economic Studies 49 (2), 201-231. 
10.Fink G., Haiss P., and Vuksic G. (2008), “Contribution of Financial Market Segments at Different Stages of Development: Transition, Cohesion and Mature Economies Compared" Journal of Financial Stability, forthcoming.

11.Fink G., Haiss P., Mantler H.C. (2005), “The Finance-Growth-Nexus:

Market Economies vs. Transition Countries, Europainstitut Working Paper 64.

12.Goldsmith R.W. (1969), "Financial Structure and Development", New Haven, CT, Yale University Press

13.Hassan, M. (2003). Can Monetary Policy Play an Effective Role in Egypt. ECES Working Paper 84.

14.Hussain and Chakraborty (2012). Causality between Financial Development and Economic Growth: Evidence from an Indian State. The Romanian Economic Journal.

15.Hussein K.A (1999), Finance and Growth in Egypt. University of Kent, Department of Economics, Canterbury CT2 7NP.

16.King R.G., Levine R. (1993a), "Finance, Entrepreneurship, and Growth: Theory and Evidence", Journal of Monetary Economics, 32(3), 513-42.

17.Levine R., Zervos S. (1996), "Stock Market Development and LongRun Growth", World Bank Economic Review, 10(2), 323-339

18.McKinnon R.I. (1973), "Money and Capital in Economic development", Washington D.C., The Brookings Institution

19. Michael Thiel (2001), Finance and Economic Growth a Review of Theory and The Available Evidence, Economic and Financial Affairs, ECFIN C3/469/01-EN

20.MMZ. (2007). Effect of Some Recent Changes in Egyptian Monetary Policy: Measurement and Evaluation. ECES Working Paper, No. 122. 
21.Mussa, M. \& Savastano, M. (1997). The IMF Support to Economic Stabilization. IMF Working Paper (WP/99/104).

22.Odhiambo, N. M. (2005), Financial Development and Economic Growth in Tanzania: a Dynamic Causality Tests. African Finance Journal 9, $1-17$.

23.Odhiambo, N. M. (2007), Supply-leading versus Demand-Following Hypothesis: Empirical Evidence fro SSA Countries. African Development Review 19, 257 - 280.

24.Odhiambo, N. M. (2008). Financial Depth, Savings and Economic Growth in Kenya: A Dynamic Causal linkage. Economic Modelling $25,704-713$.

25.Shaw E.S. (1973), "Financial Deepening in Economic Development", New York: Oxford University Press.

26.Sherif Maher Hassan (2012) Evaluation of Monetary Policy in Egypt: A Critical Review. The International Journal of Society Sciences. $30^{\text {th }}$ November. Vol. 4 No.1

27.Sindano. A, (2009), The Direction of Causal Relationship between Financial Development and Economic Growth in Namibia. Unpublished MSc.Desertitation.

28.Suleiman Abu bader and Aamer S. Abuqarn, (2005). Financial Development and Economic Growth: Time Series Evidence Egypt, Monaster Center for Economic Research, discussion paper no.05-14 July

29. Valickova P., (2012), Unpublished Masters' Thesis .Role of Financial Development in Economic Growth .A Metal -analysis.

30.Waqabaca, C. (2004) Financial Development and Economic Growth in Fiji. Working Paper 2004/03. Economics Department Reserve Bank of Fiji 


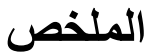

لقيت العلاقة السبيية بين تطور أسواق المال و النمو الاقتصادي الكثير من الاهتمام من جانب الباحثين، طوال السنوات الماضية، وانصب اهتمام الدر اسات السابقة على العلاقة طويلة المدى بين مستوى تطور النظام المالي، والأداء الاقتصادي، وهي العلاقة التي بدت معترف بها ومقبولة بشكل عام (جولا سميث ، 1969 ؛ كينغ وليفين ، 1993). وترجع بدايات اهتمام الباحثين بهذه العلاقة إلى البحث الذي أجراه (1934) Schumpeter ، حيث يرى بأن الوسطاء الماليين لهم دور

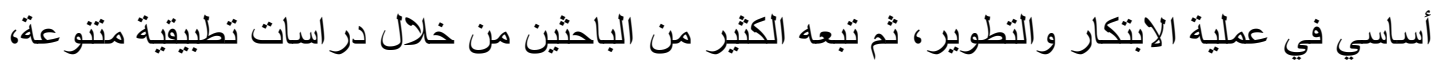
توصلت إلى نتائج متباينة بخصوص طبيعة تلك العلاقة والاتجاهات السبيية بينهما، وتستمد الدراسة

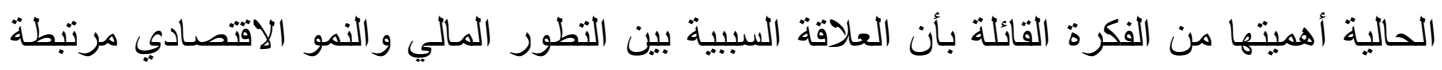

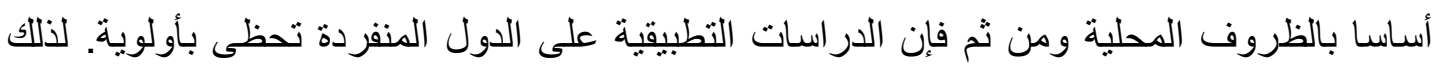

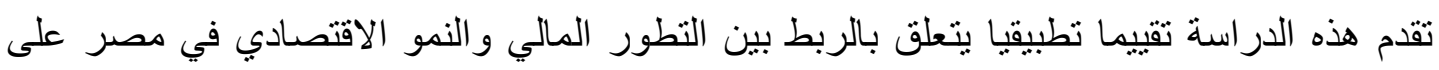
المدى الطويل وعلى المدى القصير. تستخدم الدراسة نموذج "تصحيح الخطأ المتجه (VECM)

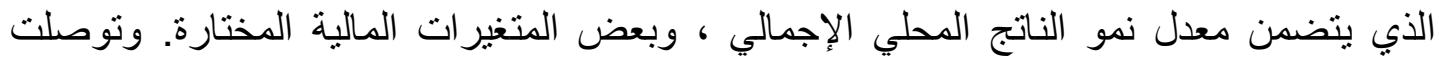

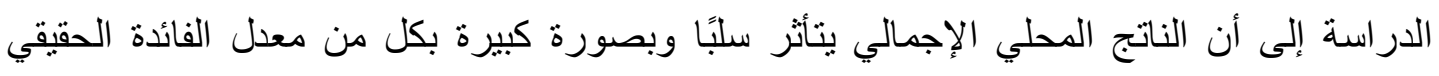

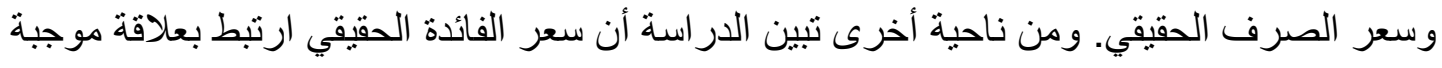

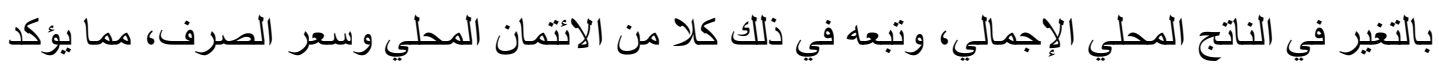
على أهمية دور التطور المالي في إحداث التنمية. 